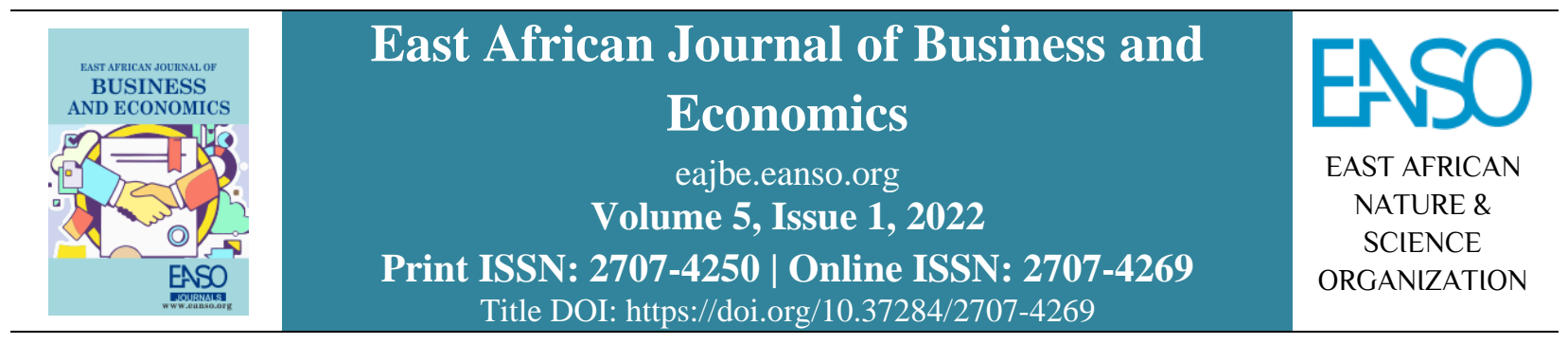

Original Article

\title{
Relationship between Mobile Banking and Financial Performance of Deposit taking savings and credit cooperatives in Kericho County, Kenya.
}

\author{
Nancy Chepkorir ${ }^{*}$, Dr. Raymond Kemboi, PhD ${ }^{1}$, Dr. Alfred Bett, PhD ${ }^{1}$ \\ ${ }^{1}$ University of Kabianga. P. O. Box 2030-20200, Kericho, Kenya. \\ * ORCID: https://orcid.org/0000-0001-7581-447X; Correspondence email: nancyjep@ yahoo.com.
}

Article DOI: https://doi.org/10.37284/eajbe.5.1.551

\section{Date Published: ABSTRACT}

15 February 2022 Deposit taking savings and credit cooperatives in Kenya have long struggled to adapt to the evolving technology which has seen several savings and credit

Keywords: cooperatives collapse as others incur losses. Mobile banking is a digital innovation that have diffused highly into financial institution creating

Mobile Banking, Financial Performance, Deposit Taking Savings, Credit Cooperatives. competitive advantage. However, there is slow uptake of mobile banking in deposit taking saving and credit cooperatives. The study therefore seeks to establish the relationship between mobile banking and financial performance of deposit taking saving and credit cooperatives in Kericho County. It was guided by task technology fit theory; a correlational research design was adopted where the target population was 108 managers of all levels in the five deposits taking savings and credit cooperatives in Kericho County. Due to a small target population under study, this research adopted the census survey technique where all top, middle, and operational level managers were used. Data were collected by the use of primary and secondary methods. Content validity was conducted through engaging field experts and digital innovation professionals to determine the validity of the research instrument, while reliability was determined through test-retest of the questionnaires where 10 respondents were picked from Tenhos Sacco Society Ltd in Bomet County for piloting. Data was analysed using both descriptive statistics which comprises means and standard deviations while hypotheses were tested using correlation coefficient and multiple regression analysis. Data was presented in form of frequency tables and pie charts. The findings established that mobile banking had a strong positive relationship with financial performance of DT-Saccos $(\mathrm{R}=0.729 ; \beta=0.775)$. The study findings may be useful to the government in formulating strategies for effective and efficient deposit taking savings and credit cooperatives; will add value to the literature in the area of digital innovations in Saccos, and lastly, it may be of help to SASRA

$62 \mid$ This work is licensed under a Creative Commons Attribution 4.0 International License. 
in understanding relationships between mobile banking and financial performance of savings and credit cooperatives.

\section{APA CITATION}

Chepkorir, N., Kemboi, R., \& Bett, A. (2022). Relationship between Mobile Banking and Financial Performance of Deposit taking savings and credit cooperatives in Kericho County, Kenya. East African Journal of Business and Economics, 5(1), 6271. https://doi.org/10.37284/eajbe.5.1.551.

\section{CHICAGO CITATION}

Chepkorir, Nancy, Raymond Kemboi, and Alfred Bett. 2022. "Relationship between Mobile Banking and Financial Performance of Deposit taking savings and credit cooperatives in Kericho County, Kenya". East African Journal of Business and Economics 5 (1), 62-71. https://doi.org/10.37284/eajbe.5.1.551.

\section{HARVARD CITATION}

Chepkorir, N., Kemboi, R., \& Bett, A. (2022) "Relationship between Mobile Banking and Financial Performance of Deposit taking savings and credit cooperatives in Kericho County, Kenya", East African Journal of Business and Economics, 5(1), pp. 62-71. doi: 10.37284/eajbe.5.1.551.

\section{IEEE CITATION}

N. Chepkorir, R. Kemboi, and A. Bett, "Relationship between Mobile Banking and Financial Performance of Deposit taking savings and credit cooperatives in Kericho County, Kenya", EAJBE, vol. 5, no. 1, pp. 62-71, Feb. 2022.

\section{MLA CITATION}

Chepkorir, Nancy, Raymond Kemboi, and Alfred Bett. "Relationship between Mobile Banking and Financial Performance of Deposit taking savings and credit cooperatives in Kericho County, Kenya". East African Journal of Business and Economics, Vol. 5, no. 1, Feb. 2022, pp. 62-71, doi:10.37284/eajbe.5.1.551.

\section{INTRODUCTION}

A digital innovation is a process where a business market or organization's operations are disrupted by innovative application of technology-based solutions (James and Prinsloo, 2017). Disruptive technologies can impact any business enterprise. While business always keep abreast with sustaining technology, they are likely to miss the mark on disruptive technologies which could threaten their information systems (Madsen \& Hartington, 2015). Businesses that take long to offer appropriate responses to disruptive technologies, often suffer losses in their competitive edge as they become exposed to threats. As the two authors assert, a firm should keep tabs on all changes taking place in its sphere of operation.

Businesses which seek a competitive edge over competitors are always introducing new products and services into the market. As disruptive technologies come into play, they force businesses to be innovative in order to address threats posed by the said technologies (Anderson \& Tushman 1990). As firms adopt new digital innovations, their growth is positively impacted, their markets are expanded, employment opportunities rise as inequalities drop, new business practices emerge, as new infrastructure is built to cater for the needs of the new products. Equally income for workers certainly rose as the labour market gets twisted to shape and distribution of income is re-organized (Leipziger \& Dodev, 2016).

In Kenya, digital innovation disruption in financial institutions revealed M-Pesa was a major breakthrough in Kenya. According to World bank report (2019) Mpesa and the rise of digital money transfer has disrupted the financial landscape which has made mobile payment and mobile baning possible becoming the Kenya norm. Accessibility of financial services was made possible because of Mobile Network Operators (MNO). This was made possible because of their network distribution, technology, and bank partnerships (Muthiora, 2015). Financial disruption was not anticipated by financial institutions simply because M-Pesa main target was low class customers whom most financial institutions saw to be a threat and risky in leading 
money. This led to them realizing later on they were losing out on business to rivals in the industry.

From the various studies DT-SACCOS are far much behind because of the adoption of information technology systems. This has led to poor financial service delivery to the members without bank accounts. Unlike the case of commercial banks which are changing to the changes of digital environment such has adopting to mobile banking which makes it easy and most convenient way clients can access their banking services at any given time. Some Saccos have started adopting digital innovative technology in order to boost accuracy, efficiency reduced costs of operation and increase customer base. This will result in increase in financial performance (Were, 2009).

Digital innovations have disrupted the financial industry and have led to turbulence that required firms to be innovative in their undertaking with the aim of improving their performance. Industries internationally were being reorganized and upturned by digital computing and new technologies (Rawashdeh, 2015). A study conducted by Berman and Payne (2018) which focused on mobile banking and internet banking as the main point of focus indicated that there had some influence on performance of financial sector. The customer base, ROE and ROA were enhanced through the adoption of these digital innovations.

Technological diffusion and digital advances have led to new ways of creating, producing, and distributing value. New market entrants with unique business models were competing with firms that had existed for a long time. An example of M-Shwari which was a partnership between Safaricom and KCB that provided banking solutions services that allowed customers to save and obtain loans from their mobile phones. Digital business strategy and models provided a space for innovation as firms redesigned how they organized and engaged customers (Berti, Mulligan \& Yap, 2017). Therefore, high increase in return on equity of
Safaricom limited company was associated with the effective implementation of mobile banking.

\section{Statement of the Problem}

Digital innovations play a key role in deposits taking saving and credit cooperatives. Organizations adopting this technology are most likely to increase efficiency, save on running costs and improvement on the quality of service delivery, thus gaining a competitive advantage. The Kenyan government has come up with a series of initiatives that encourage individuals and institutions to use ICT through the Ministry of Information and Communication Technology. Despite these initiatives by the government, Deposit-Taking Savings and Credit Cooperatives in Kenya are struggling to adapt to the evolving technology which, has seen a number of Savings and Credit Cooperatives collapse as others incur losses. The adoption of these new innovations by new and alternative financial service providers has also been caused by intensified technological innovation and customer expectations and empowerment, resulting in a whole new market for financial services. Failure by previous researchers to keep updated with the current innovations in the deposit taking SACCO's, the problems of ineffectiveness, and poor financial performances in the SACCO's are experienced. Institutions with the ability to adapt to the everchanging business environment, utilize new ideas, and come up with new innovative business methods to survive in the tough financial market. A number of forces of change have had a gross effect on some financial institutions, the use of mobile phones with technologically advanced features, and internet banking. Sadly, despite all these advancements, there is little knowledge on how mobile banking affect the financial performance of SACCOs. This study sought to assess the relationship between mobile banking adoption and financial performance by looking at DT-SACCOS in Kericho County, Kenya. 


\section{LITERATURE REVIEW}

\section{Theoretical Review}

The study was anchored in task-technology fit theory. According to Goodhue and Thompson (1995) (as cited by Maleto, 2016), the tasktechnology fit (TTF) focuses on the importance of the task at hand and the technology to be adopted. These models contain four primary devices, technology attributes, and work attributes, which jointly affect the third attribute of task technology fit. This influences the results variable, either usage or performance.

Task-technology fit theory stipulates that information technology can be adopted if its functionality is friendly to the user. The consumers of the information technology will only go for those methods and tools that can assist them in doing the task with maximum net benefits. According to Mosoti and Masheka (2010), information technology that will not generate benefits will not be adopted. Information systems are designed to help users carry out work effectively with competencies. DT-SACCOS set aside financial resources to obtain information systems that add value to their performance (Njoroge, Muhoho \& Kibuine, 2019).

Information technology is vital to SACCOs in attaining financial and diversification growth. Clients usually prefer being attended to sufficiently and faster; therefore, this has encouraged SACCOs to adapt to digital innovations technology in their operations to achieve efficiency, thus attracting customers who later become referrals leading to the growth of customer base (Muthui, 2013). If applied in different environments, the theory will result in different and specific task characteristics.

This theory will support the study specifically because it highlights the significance of digital innovation to organizations. This study's main focus was to establish the relationship between mobile banking, automated teller machine and internet banking, and financial performance, of which this theory advances the anticipated findings.

\section{Empirical Review}

Mobile banking has provided millions of people with financial solutions, especially in this dynamic environment. People have accessed financial services faster, which has led to the growth of other businesses using mobile banking. Transactions have been made easier as one can pay for goods and services with just a touch of a button.

Chiinze (2017) conducted a study in Zimbabwe that analysed the financial performance of Central Africa Building Society (CABS) after adopting mobile banking. The research determined to understand mobile banking impact on financial performance, using CABS as a case, to establish the connection between financial performance and usage of mobile banking, on the risks involved in mobile banking. Further, he investigated both internal and external factors affecting performance. The respondents were picked from the CABS' electronic banking, finance, and internal audit departments. It was evident from the findings that mobile banking usage positively affected the performance of CABS. The study recommended clients should be educated on the advantages of using mobile banking, and also, as an organization, they ought to invest more in mobile banking. More is to understand the prevailing relationships between mobile banking and financial performance, especially Saccos in Kenya.

Bagudu, Shazida, and Abdul (2017) carried out a study to understand how mobile banking affected Nigerian commercial banks. They found that mobile banking had revolutionized the banking industry entirely in Nigeria, and any bank ignoring this was doing so at its peril. The study concluded that mobile banking had shaped Nigerian commercial banks significantly. The study came to the overall conclusion that the use of mobile banking brings out a positive impact on its financial performance. The 
number of Nigerians using mobile phones and accessing the internet is growing daily; therefore, the study urged all commercial banks to embrace mobile banking in all their operations. The findings in this study might not apply in the case of Kenya simply because Nigeria is more developed technologically than Kenya and the gross domestic product and government policies of Nigeria is different from the Kenyan context.

Okiro and Ndung'u (2013) did a study to determine what impact internet and mobile banking had on the performance of Kenyan financial firms. This they did by focusing on wholesome financial institutions. Taking a sample from Nairobi County, their research established commercial banks used internet banking the most as compared to all other players in the financial environment. Other players such as SACCOs were found to be gradually embracing internet banking while many microfinance firms had not yet adopted it. The study found that mobile banking comes with its own challenges, including imposed limits on the ceiling one can transact, network failures and system delays, slow transaction processing, and high transaction cost. Fraud was found to be another major challenge.

A study to understand how mobile banking shapes the financial performance of DT-SACCOs was carried out by Bahati (2018). The study found that in the last decade, mobile banking was on a high scale in Kenya as it had facilitated faster and easier money transactions from one account to the other and across platforms. The research concluded that mobile banking bears a positive outcome on the financial performance of DT-SACCOs. The researcher recommended that the regulatory authorities lower transaction costs to encourage many people to utilize mobile banking as this makes banking easier and more convenient for clients. From the above literature review, most studies adopted a descriptive research design and a case study research design in determining the impact of mobile banking on organizational performance.

This study will adopt a correlation research design to establish the connection between mobile banking and the financial performance of Saccos in Kericho County. A study by Okiro and Ndungu (2013) indicated that mobile banking is more in use in the banking sector than in any other sector, but it is not clear whether it bears a positive or negative impact on the financial performance of financial institutions. Therefore, this study will try to ascertain if there is a relationship between mobile banking and financial performance by using correlation research design.

\section{Conceptual Framework}

In this study, mobile banking represents the independent variable while financial performance of deposit-taking Saccos represents the dependent variable measured by return on asset, return on equity, changes in customer base, and customer satisfaction.

\section{Table 1: Conceptual Frameworks}

\section{Independent Variable}

\begin{tabular}{|c|c|}
\hline $\begin{array}{l}\text { Mobile Phone Banking } \\
\text { - } \quad \text { Mobile phone banking application } \\
\text { - } \quad \text { Number of subscribers } \\
\text { - } \quad \text { Number of transactions }\end{array}$ & $\begin{array}{ll}\text { Performance of Deposit-Taking SACCOs } \\
\text { - } & \text { Return on equity } \\
\text { - } & \text { Customer base } \\
\text { - } & \text { Customer satisfaction }\end{array}$ \\
\hline
\end{tabular}


East African Journal of Business and Economics, Volume 5, Issue 1, 2022

Article DOI: https://doi.org/10.37284/eajbe.5.1.551

\section{RESEARCH METHODOLOGY}

The study used a correlational research design. The study targeted 106 managers from Imarisha, Kenya Highlands, Ndege Chai, Patnas and Simba Chai Saccos in Kericho County. Census of top, middle and lower management was used. The data was analysed using descriptive statistic where mean and standard deviation were adopted. Inferential analysis was also adopted where simple regression analysis was used.

\section{FINDINGS}

The descriptive analysis was presented in a table where frequencies and percentage were used to represented outcome in the Likert scale. While mean and standard deviation were used to describe the phenomenal under investigation. The results were presented in Table 2 and 3 which represent results of mobile banking and financial performance respectively.

Table 2: Mobile Banking and Financial Performance

\begin{tabular}{|c|c|c|c|c|c|c|c|}
\hline Statement & $\mathbf{S A}$ & $\mathbf{A}$ & $\mathbf{N}$ & D & SD & Mean & Std Dev. \\
\hline $\begin{array}{l}\text { Mobile banking application has improved } \\
\text { financial performance }\end{array}$ & $\begin{array}{l}62 \\
(60.8)\end{array}$ & $\begin{array}{l}33 \\
(32.4)\end{array}$ & $\begin{array}{l}7 \\
(6.9)\end{array}$ & 0 & 0 & 4.53 & 0.63 \\
\hline $\begin{array}{l}\text { The number of subscribers has increased } \\
\text { due to mobile banking }\end{array}$ & $\begin{array}{l}55 \\
(53.9)\end{array}$ & $\begin{array}{l}32 \\
(31.4)\end{array}$ & $\begin{array}{l}10 \\
(9.8)\end{array}$ & $\begin{array}{l}5 \\
(4.9)\end{array}$ & 0 & 4.34 & 0.85 \\
\hline $\begin{array}{l}\text { There is an increase in the number of } \\
\text { mobile banking transactions }\end{array}$ & $\begin{array}{l}57 \\
(55.9)\end{array}$ & $\begin{array}{l}38 \\
(37.3)\end{array}$ & $\begin{array}{l}7 \\
(6.9)\end{array}$ & 0 & 0 & 4.49 & 0.62 \\
\hline $\begin{array}{l}\text { Mobile banking has enabled the } \\
\text { customers to do transactions at their } \\
\text { convenient time hence time-saving }\end{array}$ & $\begin{array}{l}84 \\
(82.4)\end{array}$ & $\begin{array}{l}11 \\
(10.8)\end{array}$ & $\begin{array}{l}7 \\
(6.9)\end{array}$ & 0 & 0 & 4.75 & 0.57 \\
\hline $\begin{array}{l}\text { Mobile banking has led to an increase in } \\
\text { Saccos financial performance }\end{array}$ & $\begin{array}{l}40 \\
(39.2)\end{array}$ & $\begin{array}{l}50 \\
(49)\end{array}$ & $\begin{array}{l}12 \\
(11.8)\end{array}$ & 0 & 0 & 4.23 & 0.66 \\
\hline
\end{tabular}

$N=102$

The findings presented in Table 2 indicate that 62 (60.8) of the respondents strongly agreed as to whether mobile banking application has improved the financial performance of the DT-SACCOs, 33 (32.4) agreed, while 7(6.9) were neutral to the statement. This resulted in a mean of 4.53 and a standard deviation of 0.63 . As to whether the number of subscribers had increased due to mobile banking, 55(53.9) strongly agreed, 32 (31.4) agreed, 10(9.8) were neutral, and 5(4.9) disagreed to result in a Mean of 4.34 and a standard deviation of 0.85 . On whether there is an increase in the number of mobile banking transactions, 57 (55.9) strongly agreed; 38(37.3) agreed, while 7(6.9) were neutral, resulting in a $M=4.49$ and $S D=0.62$. When asked whether mobile banking has enabled the customers to do transactions at their convenient time hence time-saving, 84(82.4) strongly agreed, 11 (10.8) agreed, 7(6.9) were neutral, leading to a mean of 4.75 and $S D=0.57$. Finally, as to whether mobile banking has led to an increase in Sacco's financial performance, 40(39.2) strongly agreed, 50 (49) agreed, 12(11.8) were neutral, while none of the respondents disagreed or strongly disagreed. This translated to a $M=4.23$ and $S D=0.66$. 
East African Journal of Business and Economics, Volume 5, Issue 1, 2022

Article DOI: https://doi.org/10.37284/eajbe.5.1.551

Table 3: Financial Performance

\begin{tabular}{llllllll}
\hline Statement & SA & A & N & D & SD & Mean & Std Dev. \\
\hline $\begin{array}{l}\text { The number of customers in your Sacco } \\
\text { has increased for the last 3 years }\end{array}$ & 59 & 30 & 13 & 0 & 0 & 4.45 & 0.71 \\
\hline $\begin{array}{l}\text { The number of complaints from } \\
\text { customers has reduced significantly for } \\
\text { the last } 3 \text { years }\end{array}$ & $(25.5)$ & $(29.4)$ & $(12.7)$ & & & & \\
\hline $\begin{array}{l}\text { The cost of operations has been reduced } \\
\text { due to the adoption of innovation }\end{array}$ & $(40.2)$ & $(49)$ & $(26.5)$ & $(4.9)$ & $(2)$ & & \\
strategies. & & & & & & \\
\hline $\begin{array}{l}\text { The profits of Sacco have increased } \\
\text { because of digital innovations }\end{array}$ & 42 & 49 & 11 & 0 & 0.93 & 4.29 & 0.65 \\
\hline
\end{tabular}

The findings presented in Table 3 indicate that 59 (57.8) strongly agreed that the number of customers in the Sacco had increased for the last 3 years, 30(29.4) of the respondents agreed, 13(12.7) disagreed, while none of the respondents disagreed nor strongly disagreed with the statement $M=4.45$; $S D=0.71)$. On if the number of complaints from customers has reduced significantly for the last 3 years; 26(25.5) of the respondents strongly agreed, 42(41.2) agreed, 27(26.5) disagreed, 5(4.9) were neutral, while 2(2) disagreed $(M=3.83 ; S D=0.93)$. On whether the cost of operations has reduced due to the adoption of innovation strategies, 41(40.2) of the respondents strongly agreed, 50(49) agreed, 11(10.8) were neutral $(M=4.29 ; S D=0.65)$. When asked whether the profits of the Sacco had increased because of digital innovations, 42(41.2) of the respondents strongly agreed, 49(48) agreed, 11(10.8) were neutral $(M=4.30 ; S D=0.66)$.
$\boldsymbol{H}_{01}$ : There is no statistically significant relationship between mobile banking and financial performance of deposit taking savings and credit cooperatives in Kericho County.

Mobile banking was examined on financial performance where a simple linear regression was used. A simple linear regression model was given as;

$$
Y=\beta_{o}+\beta_{1} X_{1}+\varepsilon
$$

$\mathrm{Y}=$ Financial performance, $\beta_{0}=$ Constant Term, $\beta_{1}=$ Beta coefficients, $\mathrm{X}_{1}=$ mobile banking and $\varepsilon=$ Error term. Inferential statistics were analysed using simple regression model which were presented using model summary, ANOVA and Coefficient table.

Table 4: Model summary for mobile banking and financial performance

\begin{tabular}{|c|c|c|c|}
\hline Model & $\mathbf{R}$ & R Square & $\begin{array}{c}\text { Adjusted R Square Std. Error of theDurbin-Watson } \\
\text { Estimate }\end{array}$ \\
\hline 1 & $.729^{a}$ & .532 & .39251 \\
\hline
\end{tabular}

a. Predictors: (Constant), Mobile Banking

b. Dependent Variable: Financial Performance

According to the findings in Table 4 there existed strong significant relationship between mobile banking and financial performance $(R=0.729)$.

Where $53.2 \%$ of variation in financial performance

68 This work is licensed under a Creative Commons Attribution 4.0 International License. 
of DT Saccos was due to mobile banking while other factors attributed the remaining $46.2 \%\left(R^{2}=\right.$ 0.532).

Table 5: ANOVA for mobile banking and financial performance

\begin{tabular}{lllllll}
\hline Model & & Sum of Squares & df & Mean Square & F & Sig. \\
\hline \multirow{2}{*}{1} & Regression & 17.505 & 1 & 17.505 & 113.621 & $.000^{\mathrm{b}}$ \\
& Residual & 15.407 & 100 & .154 & & \\
& Total & 32.912 & 101 & & & \\
\hline
\end{tabular}

a. Dependent Variable: Financial Performance

b. Predictors: (Constant), Mobile Banking

According Table 5 results there mobile banking significantly affected the financial performance $(\mathrm{P}<0.05)$. Hence, mobile banking is among digital innovation that has significantly revolutionized the financial institutions.

Table 6: Coefficient for mobile banking and financial performance

\begin{tabular}{|c|c|c|c|c|c|c|}
\hline \multirow[t]{2}{*}{ Model } & \multicolumn{2}{|c|}{$\begin{array}{l}\text { Unstandardized } \\
\text { Coefficients }\end{array}$} & \multirow{2}{*}{$\begin{array}{l}\text { Standardized } \\
\text { Coefficients } \\
\text { Beta }\end{array}$} & \multirow[t]{2}{*}{$\mathbf{t}$} & \multicolumn{2}{|c|}{$\begin{array}{l}\text { Sig. Collinearity } \\
\text { Statistics }\end{array}$} \\
\hline & $\overline{\mathbf{B}}$ & Std. Error & & & Tolerance & VIF \\
\hline (Constant) & .864 & .317 & & 2.723 & .008 & \\
\hline Mobile banking & .775 & .073 & .729 & 10.659 & .0001 .000 & 1.000 \\
\hline
\end{tabular}

a. Dependent Variable: Financial Performance

Table 6 also revealed that a unit mobile baking contributed 0.775 effect on the financial performance $\left(\beta_{1}=0.775\right)$. Mobile banking had significant positive relationship with financial performance $(p=0.00<0.05)$. Hence, there existed positive significant relationship between mobile banking and financial performance.

These study findings concur with the findings of Chiinze (2017) and Bahati (2018) both of which indicated mobile banking had a positive significance relationship with performance. However, the studies adopted descriptive research design while the current study adopted correlational research design.

\section{CONCLUSION}

In conclusion, the findings show a statistical positive significant relationship between mobile banking and financial performance of DT-Saccos in Kericho County, Kenya. The findings on mobile banking and financial performance concluded that Saccos which have mobile banking application increases the number of subscribers, increases the number of mobile banking transactions, and enables the customers to do transactions at their convenient time hence time-saving. Therefore, this helps in increasing financial performance. In conclusion, mobile banking plays a critical role in financial performance of DT-Saccos. Therefore, there was positive significant relationship between mobile banking and financial performance.

\section{Recommendations}

The study recommends that for better financial performance, DT-Saccos need to enhance and improve their mobile banking technology because it will lead to an increase of the number of subscribers,

69 | This work is licensed under a Creative Commons Attribution 4.0 International License. 
increase in the number of mobile banking transactions, enable clients to transact at their convenient time hence time-saving, enabled the customers to do Mobile banking and this will lead to improved financial performance of the DTSaccos.

\section{REFERENCES}

Anderson, P., \& Tushman, M. L. (1990). Technological discontinuities and dominant designs: A cyclical model of technological change. Administrative science quarterly, 604633.

Bagudu, H. D., Khan, M., Jan, S., \& Roslan, A. H. (2017). The effect of mobile banking on the performance of commercial banks in Nigeria. International Research Journal of Management, IT \& Social Sciences, 4(2), 71-76.

Bahati, J. M. (2018). Effects of Mobile Banking on the Financial Performance of Deposit Taking Saccos in Kenya. University of Nairobi.

Berman, S. and Payne, P. (2018) The Interaction of Strategy and Technology in an Era of Business Re-Invention. Strategy \& Leadership, 46, 10-15.

Berti, G., Mulligan, C., \& Yap, H. (2017). Digital food hubs as disruptive business models based on Coopetition and "shared value" for sustainability in the agri-food sector. Global Opportunities for Entrepreneurial Growth: Coopetition and Knowledge Dynamics within and across Firms, 415-438.

Chiinze, H., (2017) The impact of mobile banking adoption on financial performance: a case of Central Africa Building Society (CABS).

Goodhue, D. L., \& Thompson, R. L. (1995). Tasktechnology fit and individual performance. MIS quarterly, 213-236.
James, I., \& Prinsloo, C. (2017). Digital disruption: Changing the Rules of Business. Gordon Institute of Business Science, 24.

Leipziger, D., \& Dodev, V. (2016). Disruptive technologies and their implications for economic policy: Some preliminary observations. Institute for International Economic Policy Working Paper Series, (13).

Madsen, E. S., \& Hartington, S. (2015). Disruptive technologies and networking in telecom industries. Economics Working Papers No. 2015-21. Department of Economics and Business Economics, Aarhus University.

Maleto, D. K. (2016). Effects of financial innovation on growth of savings and credit cooperatives in Kenya. Unpublished Master Thesis. University of Nairobi.

Mosoti, Z., \& Masheka, B. (2010). Knowledge management: the case for Kenya. Journal of Language, Technology \& Entrepreneurship in Africa, 2(1), 107-133.

Muthiora, B. (2015). Enabling Mobile Money Policies in Kenya: Fostering a Digital Financial Revolution. Retrieved from www.gsma.com/m mu.

Muthui, A. N. (2013). Effects of information and communication technology on corporate strategy of SACCOs in Nyeri County. Unpublished master's project. Kenyatta University. Nairobi, Kenya.

Njoroge, E. M., Muhoho, J., \& Kibuine, M. (2019). Influence of customer relationship management system on performance of deposit taking SACCOs in Nairobi County. International Academic Journal of Human Resource and Business Administration, 3(6), 179-202.

Okiro, K., \& Ndungu, J. (2013). The impact of mobile and internet banking on performance of

70 | This work is licensed under a Creative Commons Attribution 4.0 International License. 
financial institutions in Kenya. European Scientific Journal, 9(13).

Rawashden, A. (2015). Factors affecting adoption of internet banking in Jordan. International Journal of Bank Marketing, 33(4): 510-529.

SASRA. (2019). List of Sacco societies licensed to undertake deposit taking Sacco business in Kenya for the financial year ending 2019. Retrieved from: http://www.sasra.go.ke/index.p $\mathrm{hp} /$ regulation/capital-adequacy-for-deposittaking-saccos\#.V9k01jVObIU

World bank (2019). AFRONOMICS: M-Pesa and the Rise of Digital Financial Services in Africa. Retrive from https://www.worldbank.org/en/ne ws/video/2019/03/27/afronomics-m-pesa-andthe-rise-of-digital-financial-services-in-africa

71 | This work is licensed under a Creative Commons Attribution 4.0 International License. 